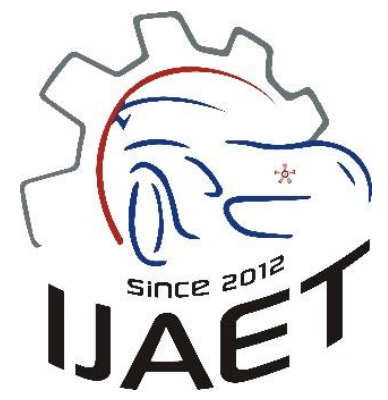

e-ISSN: 2146 - 9067

International Journal of Automotive

Engineering and Technologies

journal homepage: http://ijaet.academicpaper.org

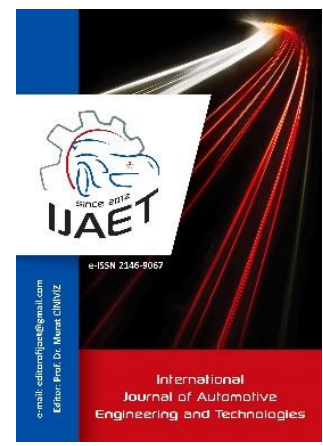

Original Research Article

\title{
Experimental study and prediction of performance and emission in an SI engine using alternative fuel with artificial neural network
}

\author{
Mustafa Kemal Balki ${ }^{1, *}$, Volkan Cavus ${ }^{2}$, İsmail Umut Duran ${ }^{2}$, Resul Tuna ${ }^{2}$, Cenk Sayin ${ }^{3}$ \\ ${ }^{1}$ Department of Mechanical Engineering, Sinop University, 57000, Sinop, Turkey \\ ${ }^{2}$ Department of Computer Technology, Sinop University, 57000, Sinop, Turkey \\ ${ }^{3}$ Department of Mechanical Engineering, Marmara University, 34722, Istanbul, Turkey
}

\section{ARTICLE INFO \\ * Corresponding author mkbalki@sinop.edu.tr \\ Department of Mechanical Engineering, Sinop University, 57000, Sinop, Turkey. \\ Tel.: +90 368 2714151; fax: +903682714152}

Received: December 28, 2017 Accepted: March 08, 2018

Published by Editorial Board Members of IJAET

(C) This article is distributed by Turk Journal Park System under the CC 4.0 terms and conditions.

\begin{abstract}
In this study, the effect of using pure ethanol in different operating conditions of a spark ignition engine was experimentally investigated, and a backpropagation artificial neural network (ANN) model was developed to estimate the engine performance and exhaust emissions. For this purpose, the spark ignition (SI) engine having a compression ratio (CR) of 8.5:1, a single cylinder and air-cooled was used in the engine tests experiments, and the ANN model was created with using the $\mathrm{C \#}$ programming language. The engine tests were, firstly, conducted for four varied CR, three types of air excess coefficient (AEC) and three different ignition timing (IGT) at $2400 \mathrm{rpm}$, and the performance and exhaust emission of the engine were recorded. Secondly, the performance and exhaust emission values of SI engine for the same test conditions were estimated with a backpropagation ANN model. The ANN model was trained with the data obtained from the experimental study. The engine torque, brake specific fuel consumption (BSFC), hydrocarbon ( $\mathrm{HC})$ emission and carbon dioxide $\left(\mathrm{CO}_{2}\right)$ emission results obtained from the pure ethanol were compared with those of the gasoline. The comparison was made separately for the same test conditions, and the changes were given as a percentage into the paper. Furthermore, the estimated performance and emission values obtained from the ANN trained with experimental data are compared with verification experiments. According to the results, it can be seen that the percentage change in the difference between the values obtained from the verification experiments, and the estimated results is acceptable. When the results are generally evaluated, it is observed that is improved of the performance and exhaust emissions as using pure ethanol at lowering the IGT and increasing the CR. When all tests are evaluated according to the best results, it is shown that engine torque and BSFC increased respectively about $11 \%$ and $51 \%(20 \mathrm{CA})$ on average while $\mathrm{CO}_{2}$ and $\mathrm{HC}$ emissions reduced about $6 \%$ and $49.2 \%$ on average. In addition, it is seen that the ANN model can be used to estimate the performance and emissions of an SI engine using alternative fuels.
\end{abstract}

Keywords: Artificial neural network; Ethanol; Engine performance; Exhaust emissions

\section{Introduction}

In today's world, energy has become the priority policy of states. It is emphasized that the strategy plans on the energy consistently have limited current petroleum reserves. Gasoline is a petroleum-based fuels. The carbon emissions that occur during its production and using in engines are harmful to the environment. The studies made to find more environmentally friendly and energy efficient by researchers continue gaining speed. On the other hand, 
researchers perform engine tests by adjusting engine variables such as ignition advance (IT), compression ratio (CR), air excess coefficient (AEC), etc. in order to obtain high efficiency through the use of alternative fuel.

Many of today's researchers have focused on the search for alternative fuels to reduce the risk of depletion of fossil fuels [1]. In this context, it appears to focus the research conducted on the use of alcohols such as ethanol and methanol as a fuel alternative to gasoline. In previous studies [2-4], it has been emphasized that the performance and emissions of a spark-ignition (SI) engine in which ethanol and methanol are used as fuels under different operating conditions are improved compared to gasoline. Ethanol $\left(\mathrm{C}_{2} \mathrm{H}_{5} \mathrm{OH}\right)$ which can be produced from agricultural yields containing glucose is a renewable alternative-fuel type. It can be utilized as pure or blended with other fuels (gasoline and diesel) in an engine [5, 6]. In addition, some studies have emphasized the improvement of thermal efficiency and exhaust emission (CO, smoke) when using ethanol as a mixture fuel with other alternative fuels [7]. It is very important to investigate in detail the effect of alternative fuels on engine performance and exhaust emissions in many operating conditions. But detailed engine tests are costly and take a lot of time. Therefore, in multivariable motor experiments, it is better to evaluate performance with modeling techniques [8]. However, the development of a correct model for the operation of an engine is very difficult due to complicated processes. Modeling performance and exhaust emission of an engine using artificial neural network (ANN) is one of the preferred methods. This model can be used to estimate the desired output parameters when sufficient experimental data is available [9].

In the literature, there are many studies in using of pure ethanol and its blend as an alternative fuel in SI engine at varied operating conditions such as CR [10-14], IGT [13,15,16] and AEC [17-19]. When these studies on the use of ethanol as fuel are examined, it is generally reported that is the improvement of the engine performance by increasing the $\mathrm{CR}$ and higher than the gasoline. At the same time, it was emphasized that there is a general improvement in exhaust emissions. In addition, it has been stated that retarding IGT and increasing AEC (at

around 1.3) has a positive effect on engine performance and exhaust emissions of an SI engine using ethanol [8-17]. In addition, in a study using biodiesel as fuel, performance and emission estimates were made with an artificial neural network, and it was emphasized that the results obtained were reliable and accurate [8]. In another similar study, the predicted results seem to have reached a high correlation coefficient [20]. In an alternative fueled study in which the ANN is used to predict cyclical variability, it is emphasized that can play an important role in reducing exhaust emissions and enhancing engine performance with using of ANN [21]. In another work using ANN for predicting a homogeneous charge compression ignition engine performance using alcohol fuel, it has been stated that engine design and performance optimization of the ANN may be used [22].

In this study, a backpropagation ANN model was created with the $\mathrm{C}$ \# programming language for estimating engine performance and exhaust emissions of an SI engine fueled pure ethanol. In order to improve the performance and exhaust emissions of a motor using ethanol, the engine was tested at four different CR and three varied IGT and AEC values at a constant engine speed of $2400 \mathrm{rpm}$. With the experimental data obtained, ANN was also trained and a model was developed for estimating performance and exhaust emissions.

Table 1. Some properties of the test fuels [10,23]

\begin{tabular}{|c|c|c|}
\hline Property & Gasoline & Ethanol \\
\hline Molar $\mathrm{C} / \mathrm{H}$ ratio & $0.44-0.50$ & 0.33 \\
\hline Density $\left(\mathrm{g} / \mathrm{cm}^{3}\right.$ at $\left.20^{\circ} \mathrm{C}\right)$ & $0.72-0.76$ & 0.790 \\
\hline $\begin{array}{l}\text { Lower heating value } \\
(\mathrm{kJ} / \mathrm{kg})\end{array}$ & 44300 & 26900 \\
\hline $\begin{array}{l}\text { Stoichiometric air/fuel } \\
\text { ratio }\end{array}$ & 14.6 & 9.0 \\
\hline Oxygen $(\% \mathrm{Wt})$ & - & 34.73 \\
\hline RON/MON & $95 / 85$ & $108.6 / 89.7$ \\
\hline $\begin{array}{l}\text { Auto-ignition temperature } \\
\left({ }^{\circ} \mathrm{C}\right)\end{array}$ & $228-470$ & 363 \\
\hline Boiling point $\left({ }^{\circ} \mathrm{C}\right)$ & $27-225$ & 78.3 \\
\hline $\begin{array}{l}\text { Heat of vaporization } \\
(\mathrm{kJ} / \mathrm{kg})\end{array}$ & 349 & 923 \\
\hline $\begin{array}{l}\text { Flammable } \\
\text { (\%volume) }\end{array}$ & $1.4-7.6$ & $3.5-15$ \\
\hline $\begin{array}{l}\text { Stoichiometric } \\
\text { speed }(\mathrm{m} / \mathrm{s})\end{array}$ & 0.34 & 0.41 \\
\hline $\begin{array}{l}\text { Adiabatic } \\
\text { temperature }\left({ }^{\circ} \mathrm{C}\right)\end{array}$ & 2002 & 1920 \\
\hline
\end{tabular}




\section{Materials and Methods}

\subsection{The engine test procedures}

In the experiments, it was used an SI engine having air-cooled, $196 \mathrm{cc}$, four-stroke and single-cylinder. The engine's CR was 8.5:1, and it had a magneto ignition system and a carbureted fuel system. Gasoline and pure ethanol were used as test fuel. The ethanol with a purity of $99 \%$ was purchased from MERCK, and some properties of test fuels were seen in Table 1.

It is used that the test setup consists of an electric dynamometer, an exhaust gas analyzer, an air and fuel metering system in order to define engine performance and exhaust emission characteristics. The exhaust emission values were determined with an MRU DELTA 1600L exhaust gas analyzer while the engine moment value is measured by a load cell mounted on the dynamometer body. The data obtained with the help of the air and fuel measurement system are used for the massive air and fuel consumption of the test engine.

All engine tests were conducted with a full throttle opening and a constant engine speed (2400 rpm), which corresponds to the maximum torque in the original operating conditions. The test engine's original ignition timing was CA of $23^{\circ}$ before top dead center, and the original compression ratio of this engine was 8.5:1. The experiments were carried out with four varied CR (8.0:1, 8.5:1, 9.0:1, and 9.5:1) at each AEC value and three different IT $\left(20,23\right.$, and $\left.26{ }^{\circ} \mathrm{CA}\right)$ at each $\mathrm{CR}$ while the engine was running at three different AEC values (0.9, 1.0, and 1.1). The carburetor main body is extended and a tapered adjusting screw is inserted in order to change of AEC. It was located with extra sealing for 8.0:1 of CR whereas the test engine's cylinder head was milled to obtain CR of 9.0:1 and 9.5:1. Triggering pulley of the magneto ignition system was replaced in the fitting position in order to set the IGT of $20^{\circ} \mathrm{CA}$ and $26^{\circ} \mathrm{CA}$ in the tests. The engine performance and exhaust emission characteristics were extracted with the help of the data obtained from the experiments.

\subsection{The modeling with $A N N$}

Artificial neural network (ANN) is an information technology developed by inspiring the human brain's information-processing technique. ANN simulates the operation of the simple biological nervous system. A common type of ANN is a multi-layer perceptron which consists of at least three layers of nodes. Backpropagation algorithm is a method used in ANN to calculate the error contribution of each neuron after processing a series of data [24]. ANN consists of three main layers. These are input, hidden, and output layers. A neuron in input layer takes in input data from external to the network. The neurons in the hidden layer process the data interacting with each other and transfer it to the output layer. The network's estimates or classifications are exported by the output layer [25]. The backpropagation ANN model used in the study is shown in Fig.1.

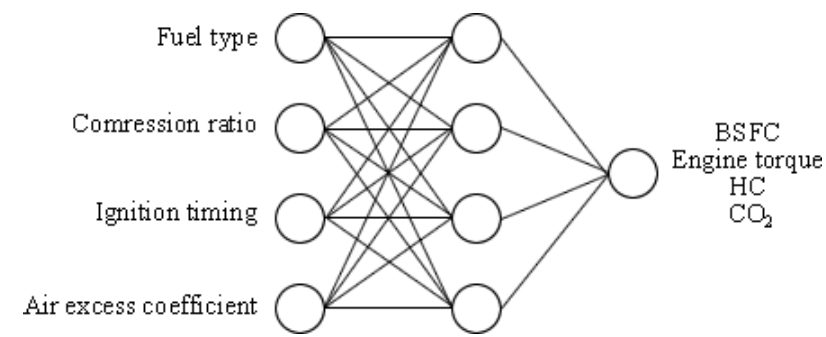

Figure 1 Design of the developed ANN model.

Fuel type, compression ratio, ignition timing and air excess coefficient are defined as the input layer in this model. Engine torque, brake specific fuel consumption, $\mathrm{HC}$ and $\mathrm{CO}_{2}$ emission values were estimated in the output layer. In the model, it was developed an interface with the $\mathrm{C \#}$ programming language to change variables such as the number of intermediate neurons, momentum and learning coefficient. With this interface, the experimental result data is read from the excel table. The ANN model was trained with experimental data, and the engine performance and exhaust emissions were estimated with the coefficients obtained as a result of the training. Approximately $70 \%$ of the data obtained from all test conditions (such as CR, IGT, AEC, type of fuel) were used in the training of ANN.

\section{Results and Discussion}

\subsection{The engine test results}

In this section, the engine torque, brake specific fuel consumption (BSFC), $\mathrm{HC}$ and $\mathrm{CO}_{2}$ emission obtained from varied test conditions are examined. The performance and emission results obtained in gasoline and ethanol fueled in the engine's original operating parameters are given in the Fig.2. 


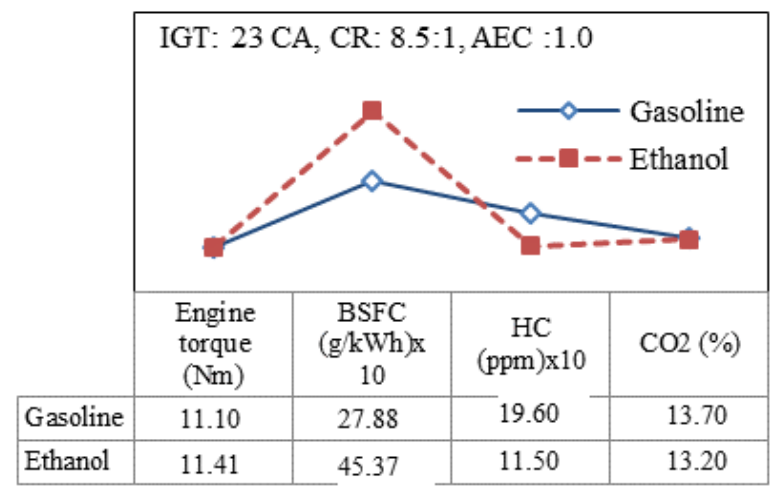

Figure 2. The value of engine performance and exhaust emissions in the original operating parameter

When the Fig 2 is examined, it is seen that the engine torque and BSFC increases with the usage of pure ethanol as compared to gasoline while the $\mathrm{HC}$ and $\mathrm{CO}$ emissions decrease.

The percent change of engine torque at the varied test conditions such as IT, CR and AEC as compared with those of gasoline are seen in Table 2. In the Table 2, it is shown that the engine torque increased with using of ethanol at the IGT of $20 \mathrm{CA}$ for all the test conditions (AEC and CR) compared to gasoline. The highest increase in the engine torque was about $21.57 \%$, and it was found to be achieved with CR of 9.5:1 and AEC of 1.0. As seen in the Table 1, it is observed that the laminar burning velocity and octane number of ethanol is higher than gasoline. These properties of ethanol shorten the burning time, and allow use at high CR (9.5:1). Therefore, it is thought that the retardation of the IGT (20 CA) causes to increase the pressure within the combustion chamber, and it is more favorable in terms of engine torque. However, the lower heating value of ethanol is lower than gasoline. This causes to increase the amount of fuel consumed per unit power. The percent change of the BSFC at the varied test conditions such as IT, CR and AEC as compared with those of gasoline are given in Table 3. As illustrated in the Table 3, the BSFC increased with the use of ethanol in generally. This increase is greater in IGT of $26 \mathrm{CA}$ while IGT of $20 \mathrm{CA}$ is less. The lowest increase was found to be at $37.56 \%$, and it was found to provide this at a high CR (9.5:1), AEC of 1.0 and IGT of $20 \mathrm{CA}$. The percent change of the $\mathrm{HC}$ and $\mathrm{CO}_{2}$ emission at the varied test conditions such as IT, CR and AEC as compared with those of gasoline are shown in Table 4 and Table 5. Features such as low molar $\mathrm{C} / \mathrm{H}$ ratio, high oxygen content and stoichiometric flame speed of ethanol compare to gasoline cause to improve the combustion efficiency. It is seen that the maximum reduction of $\mathrm{HC}$ emission by using of ethanol is at a high CR (9.0:1) and low IGT (20 CA), in Table 4. The highest reduction was found to be $54.51 \%$. However, under the same operating conditions, it was determined that $\mathrm{CO}_{2}$ emissions increased slightly, in Table 5. Any data could not be obtained in some experimental studies, and these tables were specified as none. When all the experimental results are evaluated together, it has been observed that the use of ethanol at low IGT and high CR improves generally the engine performance and emissions in SI engines. Furthermore, it has been found that while the engine performance values improve at low AEC, exhaust emissions are slightly worsened.

Table 2. Percent change of the engine torque obtained by using ethanol compared to gasoline

\begin{tabular}{|c|c|c|c|c|c|c|c|c|c|}
\hline \multirow[b]{4}{*}{ CR } & \multicolumn{3}{|c|}{ IGT (CA) } & \multicolumn{3}{|c|}{ IGT (CA) } & \multicolumn{3}{|c|}{ IGT (CA) } \\
\hline & \multicolumn{3}{|c|}{20} & \multicolumn{3}{|c|}{23} & \multicolumn{3}{|c|}{26} \\
\hline & \multicolumn{3}{|c|}{$\mathrm{AEC}$} & \multicolumn{3}{|c|}{$\mathrm{AEC}$} & \multicolumn{3}{|c|}{$\mathrm{AEC}$} \\
\hline & 0.9 & 1.0 & 1.1 & 0.9 & 1.0 & 1.1 & 0.9 & 1.0 & 1.1 \\
\hline 8.0:1 & 12.85 & 13.37 & 9.15 & 6.67 & 6.49 & 2.86 & 0.52 & 1.06 & -1.95 \\
\hline 8.5:1 & 6.08 & 10.39 & 6.73 & 1.91 & 2.75 & -2.28 & -0.90 & -4.51 & -7.85 \\
\hline 9.0:1 & 12.37 & 9.70 & 6.98 & 7.96 & 2.72 & -1.97 & 4.63 & -3.52 & -9.18 \\
\hline 9.5:1 & 15.10 & 21.57 & 7.85 & 9.72 & 14.09 & -2.63 & none & none & -6.53 \\
\hline
\end{tabular}

Table 3. Percent change of the BSFC obtained by using ethanol compared to gasoline

\begin{tabular}{|c|c|c|c|c|c|c|c|c|c|}
\hline \multirow[b]{4}{*}{ CR } & \multicolumn{3}{|c|}{ IGT (CA) } & \multicolumn{3}{|c|}{ IGT (CA) } & \multicolumn{3}{|c|}{ IGT (CA) } \\
\hline & \multicolumn{3}{|c|}{20} & \multicolumn{3}{|c|}{23} & \multicolumn{3}{|c|}{26} \\
\hline & \multicolumn{3}{|c|}{ AEC } & \multicolumn{3}{|c|}{$\overline{\mathrm{AEC}}$} & \multicolumn{3}{|c|}{ AEC } \\
\hline & 0.9 & 1.0 & 1.1 & 0.9 & 1.0 & 1.1 & 0.9 & 1.0 & 1.1 \\
\hline 8.0:1 & 48.29 & 47.51 & 53.33 & 56.89 & $\overline{57.04}$ & 62.71 & 66.48 & 65.48 & 70.69 \\
\hline 8.5:1 & 57.75 & 51.49 & 56.81 & 64.21 & 62.75 & 71.26 & 68.86 & 75.13 & 81.62 \\
\hline 9.0:1 & 48.92 & 52.45 & 56.44 & 55.01 & 65.24 & 70.71 & 59.94 & 73.33 & 84.28 \\
\hline 9.5:1 & 45.340 & 37.56 & 55.17 & 52.52 & 46.57 & 71.88 & none & none & 79.06 \\
\hline
\end{tabular}


Table 4. Percent change of the HC emission obtained by using ethanol compared to gasoline

\begin{tabular}{|c|c|c|c|c|c|c|c|c|c|}
\hline \multirow[b]{4}{*}{ CR } & \multicolumn{3}{|c|}{ IGT (CA) } & \multicolumn{3}{|c|}{ IGT (CA) } & \multicolumn{3}{|c|}{ IGT (CA) } \\
\hline & \multicolumn{3}{|c|}{20} & \multicolumn{3}{|c|}{23} & \multicolumn{3}{|c|}{26} \\
\hline & \multicolumn{3}{|c|}{ AEC } & \multicolumn{3}{|c|}{ AEC } & \multicolumn{3}{|c|}{$\mathrm{AEC}$} \\
\hline & 0.9 & 1.0 & 1.1 & 0.9 & 1.0 & 1.1 & 0.9 & 1.0 & 1.1 \\
\hline 8.0:1 & $\begin{array}{c}-48.92 \\
\end{array}$ & "-51.67 & $\begin{array}{c}-48.68 \\
\end{array}$ & 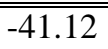 & -22.56 & -45.31 & 4.66 & 14.29 & -20.71 \\
\hline 8.5:1 & -48.54 & -48.23 & -39.80 & -37.21 & -41.33 & -32.43 & 13.16 & 36.62 & -30.72 \\
\hline 9.0:1 & -46.34 & -54.51 & -41.71 & -33.33 & -20 & -34.68 & -5.91 & 72.58 & -20.83 \\
\hline 9.5:1 & -51.66 & -50.63 & -40.20 & -49.44 & -19.61 & -29.23 & none & none & -18.33 \\
\hline
\end{tabular}

Table 5. Percent change of the $\mathrm{CO}_{2}$ emission obtained by using ethanol compared to gasoline

\begin{tabular}{|c|c|c|c|c|c|c|c|c|c|}
\hline \multirow[b]{4}{*}{ CR } & \multicolumn{3}{|c|}{ IGT (CA) } & \multicolumn{3}{|c|}{ IGT (CA) } & \multicolumn{3}{|c|}{ IGT (CA) } \\
\hline & \multicolumn{3}{|c|}{20} & \multicolumn{3}{|c|}{23} & \multicolumn{3}{|c|}{26} \\
\hline & \multicolumn{3}{|c|}{ AEC } & \multicolumn{3}{|c|}{$\mathrm{AEC}$} & \multicolumn{3}{|c|}{$\mathrm{AEC}$} \\
\hline & 0.9 & 1.0 & 1.1 & 0.9 & 1.0 & 1.1 & 0.9 & 1.0 & 1.1 \\
\hline 8.0:1 & 3.17 & 4.03 & 0 & 0.78 & -1.54 & -3.82 & -3.08 & -5.26 & -6.82 \\
\hline $8.5: 1$ & 0 & 5.51 & -2.22 & -2.21 & -3.65 & -6.47 & -7.09 & -7.14 & -7.98 \\
\hline 9.0:1 & 6.87 & 5.30 & 0 & 1.48 & -4.26 & -7.04 & -1.46 & -8.33 & -9.09 \\
\hline 9.5:1 & 10.48 & 6.25 & 6.35 & 7.14 & 4.72 & 0 & none & none & -3.03 \\
\hline
\end{tabular}

\subsection{ANN Results}

In this section, the comparison of the experimental results and the predicted results obtained from the ANN model is shown in Fig. 3 (a, b, c, d).

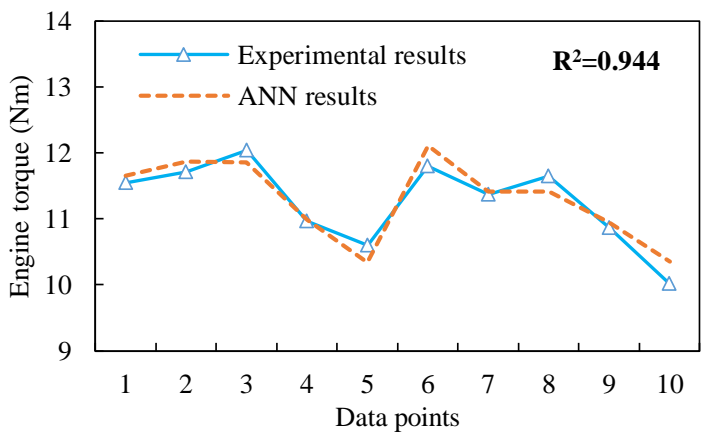

a.) For engine torque

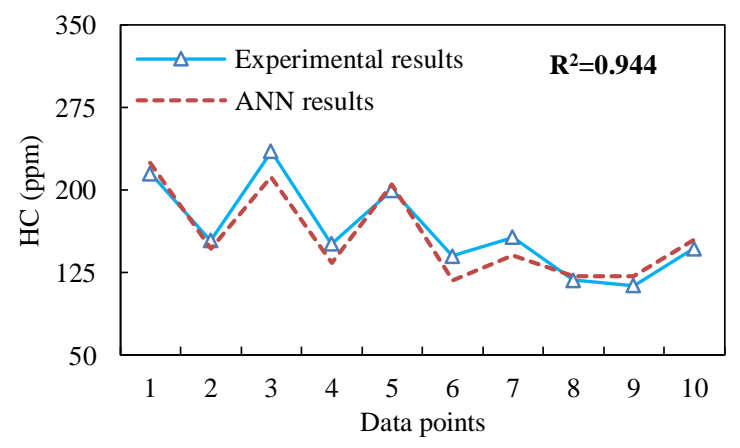

c.) For $\mathrm{HC}$

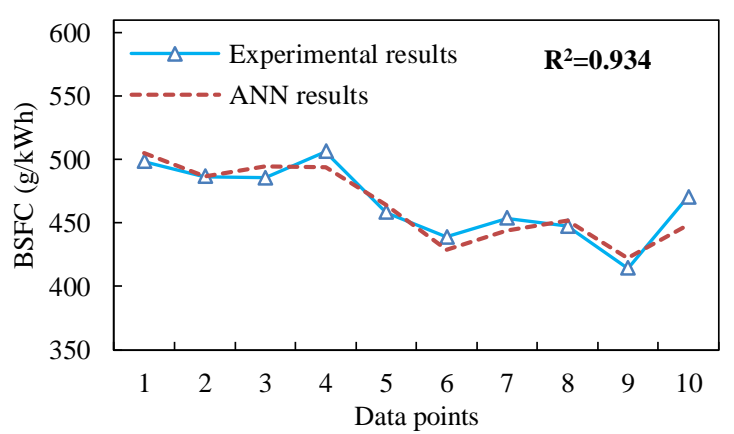

b.) For BSFC

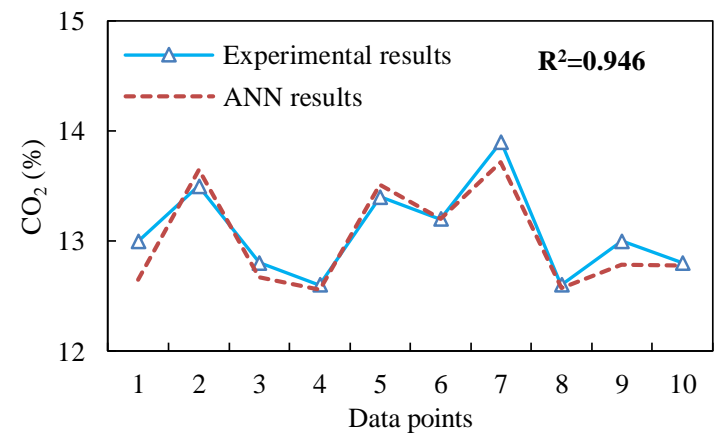

d.) For $\mathrm{CO}_{2}$

Figure 3. Comparison of the experimental results and the ANN results

When all the results are evaluated, it is seen that the correlation coefficient R2, which shows the correspondence between the estimation and the experimental results, is close to 1 . When each graph is separately examined, it is determined to be a similarity between the estimated values and the experimental data. The error averages for the differences are calculated as $1.56 \%$ for engine torque, $1.89 \%$ for $\mathrm{BSFC}, 7.54 \%$ for $\mathrm{HC}$ and $0.94 \%$ for $\mathrm{CO}_{2}$. It is seen that the error rates are within acceptable limits. The results showed that ANN could be used to determine 
performance and emissions with very different variables in alternative fuel studies.

\section{Conclusion}

In this paper, it was investigated the effect of varied operating parameters such as CR, AEC and $\mathrm{CR}$ on the engine performance and exhaust emission of SI engine used of alternative fuel. In addition, the performance and exhaust emission of the engine were estimated with an ANN model created $\mathrm{C \#}$ programming language. The results are as follows:

- When all the results were evaluated, the engine torque with the use of ethanol increased by an average of $7.25 \%$ compared to gasoline. It was determined that the highest increase occurred at IGT of $20 \mathrm{CA}$ and reached the highest value with increasing the $\mathrm{CR}$ at $\mathrm{AEC}$ of 1.0. The BSFC has increased in general, but an improvement has been observed with the increase in the engine torque.

- The $\mathrm{HC}$ and $\mathrm{CO}_{2}$ emissions obtained from using ethanol were reduced by about $28 \%$ and $0.8 \%$ on average for all studies compared to gasoline. The reduction in $\mathrm{HC}$ emission was found to be greater at $20 \mathrm{CA}$ (IGT). However, the $\mathrm{CO}_{2}$ emission raised slightly under the same operating conditions.

- It has been found that the R2 values obtained from the ANN model are close to 1 for all output parameters. In addition, it has been determined that the percentages of the difference between the predicted with the experimental results are in acceptable levels. The results have been shown that the backpropagation ANN can be used in extensive studies investigating the effect of alternative fuel on engine performance and emissions.

- It has been determined that the use of ethanol as fuel in engine operating parameters optimized for spark ignition engines will improve engine performance and exhaust emissions. With the established artificial neural network model, these optimizations can be made as well as estimated results without experimentation.

\section{References}

[1] B. Dhinesh, R. Niruban Bharathi, J. Isaac JoshuaRamesh Lalvani, M. Parthasarathy, K. Annamalai. An experimental analysis on the influence of fuel borne additives on the single cylinder diesel engine powered by Cymbopogon flexuosus biofuel. Journal of the Energy Institute. 90 (2017) 634-45.

[2] M.K. Balki, C. Sayin. The effect of compression ratio on the performance, emissions and combustion of an SI (spark ignition) engine fueled with pure ethanol, methanol and unleaded gasoline. Energy. 71 (2014) 194-201.

[3] M.K. Balki, C. Sayin, M. Canakci. The effect of different alcohol fuels on the performance, emission and combustion characteristics of a gasoline engine. Fuel. 115 (2014) 901-6.

[4] M.K. Balki, C. Sayin, M. Sarıkaya. Optimization of the operating parameters based on Taguchi method in an SI engine used pure gasoline, ethanol and methanol. Fuel. 180 (2016) 630-7.

[5] C.A. Srinivasan, C. Saravanan. Study of combustion characteristics of an SI engine fuelled with ethanol and oxygenated fuel additives. Journal of Sustainable Energy \& Environment. 1 (2010) 85-91.

[6] S. Yousufuddin. Experimental study on combustion duration and performance characteristics of a hydrogen-ethanol dual fueled engine. International Journal of Automotive Engineering and Technologies. 5 (2016) 85-101.

[7] M. Parthasarathy, J. Isaac JoshuaRamesh Lalvani, B. Dhinesh, K. Annamalai. Effect of hydrogen on ethanol-biodiesel blend on performance and emission characteristics of a direct injection diesel engine. Ecotoxicol Environ Saf. 134 (2016) 433-9.

[8] S. Dharma, M.H. Hassan, H.C. Ong, A.H. Sebayang, A.S. Silitonga, F. Kusumo, et al. Experimental study and prediction of the performance and exhaust emissions of mixed Jatropha curcas-Ceiba pentandra biodiesel blends in diesel engine using artificial neural networks. Journal of Cleaner Production. 164 (2017) 618-33.

[9] C. Sayin, H.M. Ertunc, M. Hosoz, I. Kilicaslan, M. Canakci. Performance and exhaust emissions of a gasoline engine using artificial neural network. Appl Therm Eng. 27 (2007) 46-54.

[10] M.B. Celik. Experimental determination of suitable ethanol-gasoline blend rate at high 
compression ratio for gasoline engine. Appl Therm Eng. 28 (2008) 396-404.

[11] M. Koç, Y. Sekmen, T. Topgül, H.S. Yücesu. The effects of ethanol-unleaded gasoline blends on engine performance and exhaust emissions in a spark-ignition engine. Renew Energ. 34 (2009) 2101-6.

[12] R.C. Costa, J.R. Sodré. Compression ratio effects on an ethanol/gasoline fuelled engine performance. Appl Therm Eng. 31 (2011) 278-83.

[13] H.S. Yücesu, A. Sozen, T. Topgül, E. Arcaklioğlu. Comparative study of mathematical and experimental analysis of spark ignition engine performance used ethanol-gasoline blend fuel. Appl Therm Eng. 27 (2007) 358-68.

[14] H.S. Yücesu, T. Topgül, C. Çinar, M. Okur. Effect of ethanol-gasoline blends on engine performance and exhaust emissions in different compression ratios. Appl Therm Eng. 26 (2006) 2272-8.

[15] R. Daniel, G. Tian, H. Xu, S. Shuai. Ignition timing sensitivities of oxygenated biofuels compared to gasoline in a directinjection SI engine. Fuel. 99 (2012) 72-82.

[16] T. Topgül, H.S. Yücesu, C. Çinar, A. Koca. The effects of ethanol-unleaded gasoline blends and ignition timing on engine performance and exhaust emissions. Renew Energ. 31 (2006) 2534-42.

[17] C.-W. Wu, R.-H. Chen, J.-Y. Pu, T.-H. Lin. The influence of air-fuel ratio on engine performance and pollutant emission of an SI engine using ethanol-gasoline-blended fuels. Atmos Environ. 38 (2004) 7093-100.

[18] C. Park, Y. Choi, C. Kim, S. Oh, G. Lim, Y. Moriyoshi. Performance and exhaust emission characteristics of a spark ignition engine using ethanol and ethanol-reformed gas. Fuel. 89 (2010) 2118-25.

[19] I. Schifter, L. Diaz, R. Rodriguez, J.P. Gómez, U. Gonzalez. Combustion and emissions behavior for ethanol-gasoline blends in a single cylinder engine. Fuel. 90 (2011) 3586-92.

[20] K. Prasada Rao, T. Victor Babu, G. Anuradha, B.V. Appa Rao. IDI diesel engine performance and exhaust emission analysis using biodiesel with an artificial neural network (ANN). Egyptian Journal of Petroleum. 26 (2017) 593-600.
[21] S. Gürgen, B. Ünver, İ. Altın. Prediction of cyclic variability in a diesel engine fueled with n-butanol and diesel fuel blends using artificial neural network. Renew Energ. 117 (2018) 538-44.

[22] J. Rezaei, M. Shahbakhti, B. Bahri, A.A. Aziz. Performance prediction of $\mathrm{HCCI}$ engines with oxygenated fuels using artificial neural networks. Appl Energ. 138 (2015) 460-73.

[23] MERC. Product specification; Germany. 2017.

[24] H. Soukht Saraee, H. Taghavifar, S. Jafarmadar. Experimental and numerical consideration of the effect of $\mathrm{CeO} 2$ nanoparticles on diesel engine performance and exhaust emission with the aid of artificial neural network. Appl Therm Eng. 113 (2017) 663-72.

[25] V. Cavus, A. Tuncer. An Application Interface Design for Backpropagation Artificial Neural Networks. ICCDMME 2015 International Conference On Computer Sciance, Data Mining and Mechanical Engineering, Bangkok (Thailand), 2015. pp. 100-3. 